\title{
Case Report: Successful treatment of refractory high-flow priapism in a patient with sickle cell disease by selective
} trans-catheter embolization using an autologous blood clot: A case report [version 1; peer review: 1 approved with reservations, 1 not approved]

\author{
Muhammad Tahir (D1), Hiba A. Abbas¹, Tariq Tassadaq² \\ ${ }^{1}$ Department of Radiology, Saad Specialist Hospital, Al-Khobar, 31952, Saudi Arabia \\ ${ }^{2}$ Department of Urology, Saad Specialist Hospital, Al-Khobar, 31952, Saudi Arabia
}

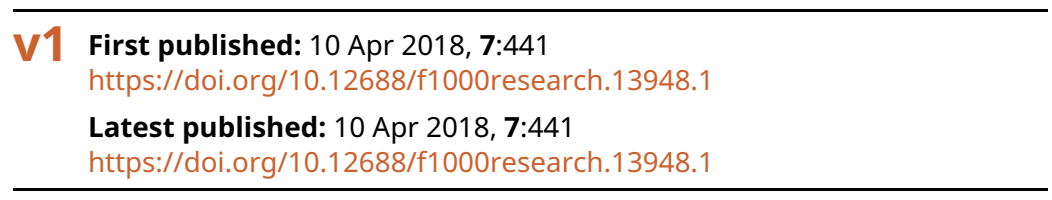

\section{Abstract}

Priapism is an abnormal prolonged and persistent penile erection lasting more than $4 \mathrm{~h}$, unrelated to sexual desire, stimulation or activity. The three types of priapism are low-flow, high-flow and stuttering. Patients with sickle cell disease (SCD) have increased risk of low-flow and stuttering priapism, but high-flow priapism is relatively uncommon in SCD. We report a case of non-traumatic refractory highflow priapism evolving from a stuttering low-flow priapism in a patient with SCD. The patient was successfully treated by super-selective transcatheter embolization of the penile arteries with an autologous blood clot. It is proposed that the super-selective transcatheter embolization of unilateral or bilateral penile arteries with autologous blood clot is a relatively safe and effective non-surgical treatment option for high-flow priapism, even in patients with SCD, and has a low probability of developing erectile dysfunction.

\section{Keywords}

sickle cell, priapism, autologous, embolization.

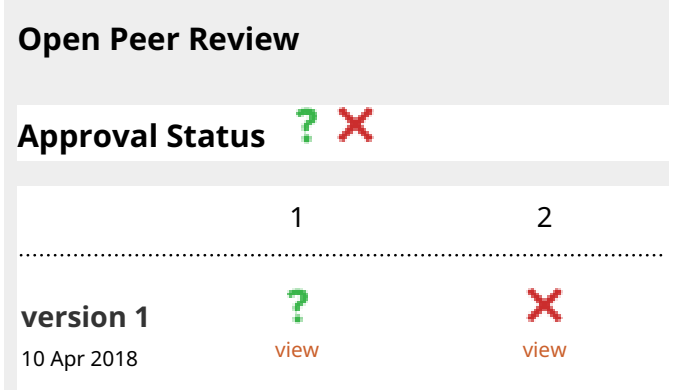

1. Arthur L. Burnett, The Johns Hopkins

Medical Institutions, Baltimore, USA

2. David J. Ralph, University College London

Hospital, London, UK

Any reports and responses or comments on the article can be found at the end of the article. 
Corresponding author: Muhammad Tahir (drmtahir@gmail.com)

Author roles: Tahir M: Conceptualization, Investigation, Methodology, Project Administration, Resources, Writing - Original Draft Preparation, Writing - Review \& Editing; Abbas HA: Data Curation; Tassadaq T: Data Curation, Resources

Competing interests: No competing interests were disclosed.

Grant information: The author(s) declared that no grants were involved in supporting this work.

Copyright: $\odot 2018$ Tahir M et al. This is an open access article distributed under the terms of the Creative Commons Attribution License, which permits unrestricted use, distribution, and reproduction in any medium, provided the original work is properly cited.

How to cite this article: Tahir M, Abbas HA and Tassadaq T. Case Report: Successful treatment of refractory high-flow priapism in a patient with sickle cell disease by selective trans-catheter embolization using an autologous blood clot: A case report [version 1; peer review: 1 approved with reservations, 1 not approved] F1000Research 2018, 7:441

https://doi.org/10.12688/f1000research.13948.1

First published: 10 Apr 2018, 7:441 https://doi.org/10.12688/f1000research.13948.1 


\section{Introduction}

Priapism is an abnormal prolonged and persistent penile erection lasting for more than $4 \mathrm{~h}$ that is unrelated to sexual desire, stimulation or activity ${ }^{1-5}$. Priapism is categorized into three types: low-flow (ischemic, veno-occlusive), high-flow (non-ischemic, arterial), and stuttering (recurrent or intermittent ischemic) ${ }^{5}$. The low-flow or ischemic form is painful and is the commonest type of priapism $(95 \%)^{4}$. High-flow or non-ischemic priapism is rare, painless and is commonly associated with pelvic, perineal or direct penile trauma due to injury to the cavernous artery ${ }^{6-9}$. Stuttering priapism is ischemic in nature associated with multiple recurrent intermittent self-limiting episodes of persistent erection usually lasting less than 3-4 h and its commonest cause is sickle cell disease $(\mathrm{SCD})^{5}$. Patients with SCD have an increased risk of low-flow and stuttering priapism, but high-flow priapism is relatively uncommon in these patients ${ }^{5}$.

We report a case of non-traumatic refractory high-flow priapism evolving from a stuttering low-flow priapism in a SCD patient. The patient was successfully treated by superselective transcatheter embolization of the penile arteries with an autologous blood clot.

\section{Case report}

A 37-year-old patient, who was known to have SCD, glucose-6-phosphate dehydrogenase deficiency and hypertension, presented with priapism. Initially, he developed self-limiting intermittent episodes of sustained erection without sexual excitation for 3 months. Each episode lasted for less than $2 \mathrm{~h}$. Eventually he presented with a sustained erection for 12 days duration in another facility, where he received treatment for low-flow priapism by repeated corporal aspirations and transfusion of 3 units of blood with no detumescence. He was then referred to our hospital with refractory priapism associated with SCD.

The patient's blood results revealed a hemoglobin level of $8.9 \mathrm{~g} / \mathrm{dl}$ (normal, 14-18 g/dl), with $94.7 \%$ hemoglobin S. The patient was treated with intravenous hydration and alkalization, nasal oxygen and exchange transfusion. Aspiration of the corpora revealed bright red blood. The patient did not have any significant penile pain at any stage. Color Doppler ultrasound imaging demonstrated a marked increase in the flow of the penile arteries. There were no features of arterio-cavernous fistula or psuedoaneurysm.

After discussing the possibility of impotence, the patient agreed for selective embolotherapy. Following the obtainment of written informed consent, pelvic digital subtraction angiography was performed via a right transfemoral artery approach. A 5 French vascular access sheath was placed in the right common femoral artery and a 5 French $\mathrm{C} 2$ catheter was engaged in the right internal iliac artery. A 2.4 French microcatheter was advanced coaxially into the ipsilateral internal pudendal artery, which was embolized with an autologous blood clot (Figure 1 and Figure 2). The $\mathrm{C} 2$ catheter was then engaged in to the contralateral left internal iliac artery using the cross-over technique and the left internal pudendal artery was embolized with an autologous blood clot after selective catheterization with a microcatheter (Figure 3 and Figure 4).

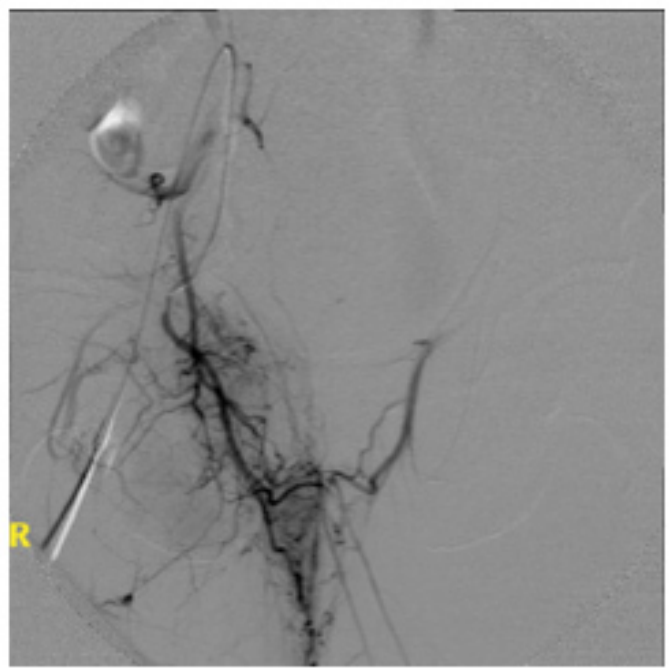

Figure 1. Right internal pudendal artery angiogram (preembolization).

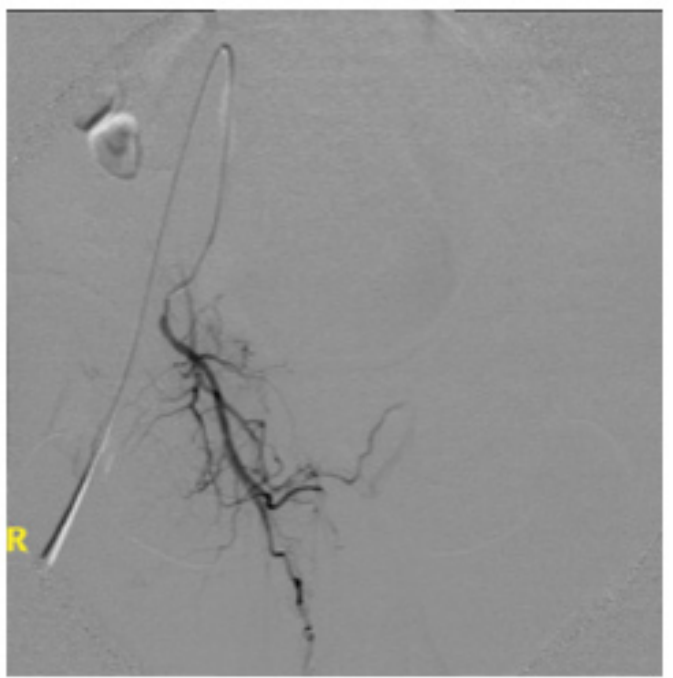

Figure 2. Right internal pudendal artery angiogram (postembolization). 


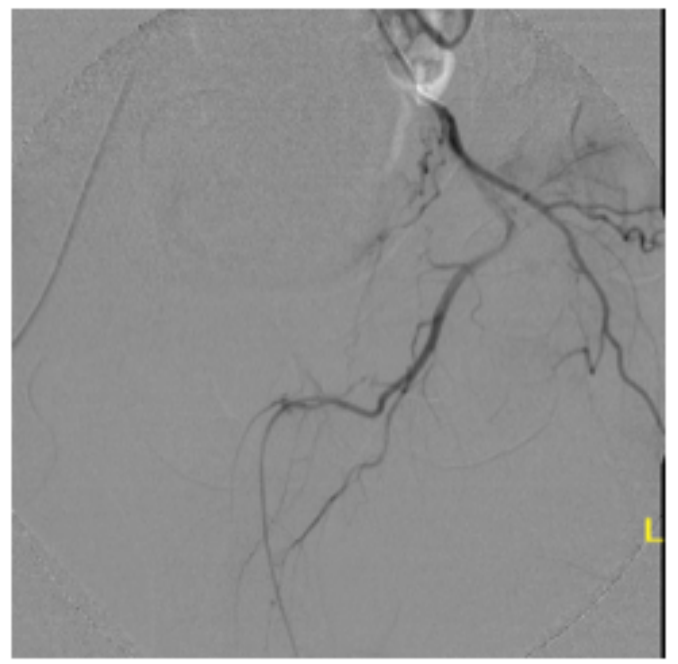

Figure 3. Pre-embolization arteriogram of the left internal pudendal artery.

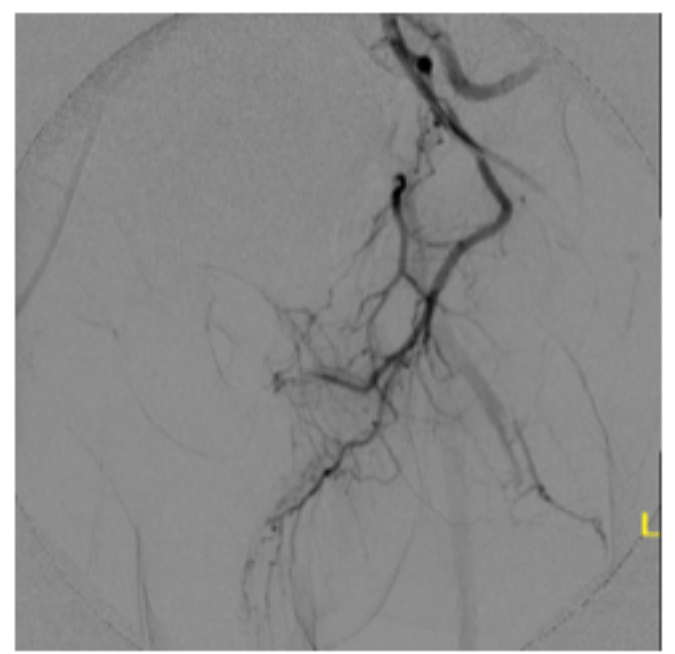

Figure 4. Post-embolization arteriogram of the left internal pudendal artery.

There was incomplete detumescence of the penis. Mild tumescence was expected due to considerable cavernous tissue fibrosis. Reduced blood flow was seen in the penile arteries on color Doppler ultrasound after transcatheter embolization. There were no further episodes of priapism and he had adequate self-limiting erections for intercourse.

\section{Discussion}

Ischemic priapism is an emergency due to the potential risk of developing permanent erectile dysfunction, whereas non-ischemic priapism can be treated conservatively or less aggressively ${ }^{10}$. Patient history, physical examination, aspirated blood gases and penile Doppler ultrasonography help to categorize priapism into ischemic and non-ischemic types for its appropriate management. In the ischemic form of the priapism, fully rigid corpora cavernosa; relative sparing or little involvement of the corpus spongiosum and glans penis; hypoxic and dark aspirated corporal blood; and absent or minimal arterial blood flow are $\operatorname{see}^{10}$. In the non-ischemic type, the corpora cavernosa are not fully rigid, the aspirated corporal blood is bright red without hypoxia or acidosis and is associated with increased blood flow, arteriolar-sinusoidal fistula or pseudoaneurysm ${ }^{10}$. Doppler ultrasound study of penile arteries can be helpful in cases with equivocal clinical findings, where mean and peak systolic velocities can differentiate between ischemic and nonischemic forms ${ }^{11}$.

Low-flow priapism is initially managed with intravenous hydration, alkalization, analgesia and exchange transfusion ${ }^{4}$. However, if priapism persists, further treatment includes corporeal blood aspiration, irrigation with non-heparinized saline and intracorporeal administration of alpha-adrenergic agonists (sympathomimetic agents such as phenylephrine) ${ }^{4}$. The surgical shunt procedure is the last resort when all attempts of other nonsurgical treatment options have failed ${ }^{4,12}$. The initial management of high-flow priapism is observation and two-thirds of high-flow priapism patients resolve spontaneously during observation ${ }^{13,14}$. In the rest of the patients with high-flow priapism, embolotherapy is a frequent treatment option, which can be performed in a number of way, including by use of autologous blood clot, gel foam, platinum microcoils or acrylic glue ${ }^{10,15-17}$. Complications of embolization can include permanent erectile dysfunction, penile gangrene, inadvertent migration of the embolization material into other regional arteries, gluteal ischemia and perineal abscesses ${ }^{18}$. Autologous blood clot embolotherapy has been reported in post-traumatic high-flow priapism patients ${ }^{19}$. In our case, after the failure of initial management by corporeal aspiration, the non-traumatic high-flow state was successfully treated using autologous blood clot embolotherapy. The autologous blood clot and gelatin foam have transient effect as embolization agents ${ }^{20}$ and their use in high-flow priapism patients has the theoretical advantage of recanalization of penile arteries, as compared to platinum microcoils, to reduce the risk of permanent erectile dysfunction. Embolization can be repeated in cases of recurrence. If embolotherapy fails, surgical management is the last treatment option ${ }^{21}$.

\section{Conclusions}

Super selective embolization of unilateral or bilateral penile arteries with autologous blood clot is a relatively safe and effective non-surgical treatment option for high-flow priapism, even in patients with SCD and has a low risk of erectile dysfunction.

\section{Consent}

The patient provided written informed consent for the publication of this case report.

\section{Data availability}

All data underlying the results are available as part of the article and no additional source data are required. 


\section{Competing interests}

No competing interests were disclosed.
Grant information

The author(s) declared that no grants were involved in supporting this work.
1. Morrison BF, Burnett AL: Stuttering Priapism: Insights into pathogenesis and management. Curr Urol Rep. 2012; 13(4): 268-276.

PubMed Abstract | Publisher Full Text

2. Burnett AL, Bivalacqua TJ: Priapism: current principles and practice. Urol Clin North Am. 2007; 34(4): 631-642, viii.

PubMed Abstract | Publisher Full Text

3. Bivalacqua TJ, Burnett AL: Priapism: New Concepts in the Pathophysiology and New Treatment Strategies. Curr Urol Rep. 2006; 7(6): 497-502. PubMed Abstract | Publisher Full Text

4. Broderick GA, Kadioglu A, Bivalacqua TJ, et al:: Priapism: pathogenesis, epidemiology, and management. J Sex Med. 2010; 7(7): 476-500. PubMed Abstract | Publisher Full Text

5. Levey HR, Kutlu O, Bivalacqua TJ: Medical management of ischemic stuttering priapism: a contemporary review of the literature. Asian J Androl. 2012; 14(1): 156-163.

PubMed Abstract | Publisher Full Text | Free Full Text

6. Broderick GA: Priapism and sickle-cell anemia: Diagnosis and nonsurgical therapy. J Sex Med. 2012; 9(1): 88-103. PubMed Abstract | Publisher Full Text

7. Abujudeh H, Mirsky D: Traumatic high-flow priapism: treatment with superselective micro-coil embolization. Emerg Radiol. 2005; 11(6): 372-374. PubMed Abstract | Publisher Full Text

8. Baba Y, Hayashi S, Ueno K, et al.: Superselective arterial embolization for patients with high-flow priapism: results of follow-up for five or more years. Acta Radiol. 2007; 48(3): 351-354. PubMed Abstract | Publisher Full Text

9. Hellstrom WJ, Derosa A, Lang E: The use of transcatheter superselective embolization to treat high flow priapism (arteriocavernosal fistula) caused by straddle injury. J Urol. 2007; 178(3 Pt 1): 1059. PubMed Abstract | Publisher Full Text

10. Shigehara K, Namiki M: Clinical Management of Priapism: A Review. World J Mens Health. 2016; 34(1): 1-8. Mens Health. 2016; 34(1): 1-8.
PubMed Abstract | Publisher Full Text | Free Full Text

11. von Stempel C, Zacharakis E, Allen C, et al: Mean velocity and peak systolic velocity can help determine ischaemic and non-ischaemic priapism. Clin
Radiol. 2017; 72(7): 611.e9-611.e16.

PubMed Abstract | Publisher Full Text

12. Wen CC. Munarriz R, McAuley I, et al.: Management of ischemic priapism with high-dose intracavernosal phenylephrine: from bench to bedside. J Sex Med. 2006; 3(5): 918-922.

PubMed Abstract | Publisher Full Text

13. Montague DK, Jarrow J, Broderick GA, et al.: American Urological Association guideline on the management of priapism. J Urol. 2003; 170(4 Pt 1): 1318-1324. PubMed Abstract | Publisher Full Text

14. Shrewsberry A, Weiss A, Ritenour CW: Recent Advances in the Medical and Surgical Treatment of Priapism. Curr Urol Rep. 2010; 11(6): 405-413. PubMed Abstract | Publisher Full Text

15. Hetzichristou D, Salpiggidis G, Hatzimouratidis K, et al:: Management strategy for arterial priapism: therapeutic dilemmas. J Urol. 2002; 168(5): 2074-2077. PubMed Abstract

16. Takao T, Osuga K, Tsujimura A, et al:: Successful superselective arterial embolization for post-traumatic high-flow priapism. Int J Urol. 2007; 14(3): 254-256. PubMed Abstract | Publisher Full Text

17. Hakim LS, Kulaksizoglu H, Mulligan R, et al:: Evolving concepts in the diagnosis and treatment of arterial high flow priapism. J Urol. 1996; 155(2): 541-8. PubMed Abstract | Publisher Full Text

18. Sandock DS, Seftel AD, Herbener TE, et al:: Perineal abscess after embolization for high-flow priapism. Urology. 1996; 48(2): 308-311. PubMed Abstract | Publisher Full Text

19. Crummy AB, Ishizuka J, Madsen PO: Posttraumatic priapism: successful treatment with autologous clot embolization. AJR Am J Roentgenol. 1979; 133(2): 329-330.

PubMed Abstract | Publisher Full Text

20. Burt FB, Schirmer HK, Scott WW: A new concept in the management of priapism. J Urol. 1960; 83: 60-61. PubMed Abstract | Publisher Full Text

21. Salonia A, Eardley I, Giuliano F, et al.: European Association of Urology Guidelines on Priapism. Eur Urol. 2014; 65(2): 480-489. PubMed Abstract | Publisher Full Text 


\section{Open Peer Review}

\section{Current Peer Review Status: ? $\mathrm{X}$}

\section{Version 1}

Reviewer Report 08 May 2018

https://doi.org/10.5256/f1000research.15162.r33414

(C) 2018 Ralph D. This is an open access peer review report distributed under the terms of the Creative Commons Attribution License, which permits unrestricted use, distribution, and reproduction in any medium, provided the original work is properly cited.

\section{David J. Ralph}

Andrology Department, University College London Hospital, London, UK

I have reviewed the article and here are my comments:

This patient had the wrong diagnosis made and potentially could have had a disastrous complication of penile gangrene.

The diagnosis was ischaemic priapism of 12 days and the initial treatment was correct but deemed a failure.

After aspiration in this context a hyperdynamic flow occurs due to a reactive hyperaemia with reperfusion.

The Doppler performed after aspiration therefore records a high flow whereas the perfusion within the small vessels and tissues is absent and is necrotic and later fibroses down.

To then embolise a penis that already has necrotic tissue is dangerous.

This patient did not have high flow priapism.

Is the background of the case's history and progression described in sufficient detail? No

Are enough details provided of any physical examination and diagnostic tests, treatment given and outcomes?

Partly

Is sufficient discussion included of the importance of the findings and their relevance to future understanding of disease processes, diagnosis or treatment? 
No

Is the case presented with sufficient detail to be useful for other practitioners? No

Competing Interests: No competing interests were disclosed.

I confirm that I have read this submission and believe that I have an appropriate level of expertise to state that I do not consider it to be of an acceptable scientific standard, for reasons outlined above.

Reviewer Report 04 May 2018

https://doi.org/10.5256/f1000research.15162.r33413

(c) 2018 Burnett A. This is an open access peer review report distributed under the terms of the Creative Commons Attribution License, which permits unrestricted use, distribution, and reproduction in any medium, provided the original work is properly cited.

\section{Arthur L. Burnett}

Department of Urology, The James Buchanan Brady Urological Institute, The Johns Hopkins Medical Institutions, Baltimore, Maryland, 21287-2411, USA

You provide an intriguing report and suggest a new treatment consideration for priapism. This specifically applies to the patient who has non-traumatic refractory high-flow priapism that apparently has evolved from a low-flow state in a sickle cell disease patient. Your success is applauded. There are some questions.

1. Some important data would be helpful to include to convince the reader about your findings. For instance, do you have the data for arterial blood gas measurement from the penis with blood aspiration that correlates with your observation of bright red blood? What were the color Doppler ultrasound imaging parameters that are increased? What were the reduced blood flow parameters after treatment? Perhaps a simple table of before and after blood flow parameters by the ultrasound technique would be very helpful for the reader.

2. A strong suggestion is to include arrows on your figures to show exactly where the embolization was performed. Legends for each figure can then specify the observation based on the location of the arrow.

3. Although this has been a successful technique, it is clear that it has a role specifically in this sort of patient only after high-flow priapism has been confirmed. This would not be a technique that would mistakenly be done for low-flow priapism. Otherwise, serious complications could be expected in the latter condition. It is suggested to the authors to emphasize this point strongly in your conclusion statement.

Is the background of the case's history and progression described in sufficient detail? Yes

Are enough details provided of any physical examination and diagnostic tests, treatment 
given and outcomes?

No

Is sufficient discussion included of the importance of the findings and their relevance to future understanding of disease processes, diagnosis or treatment?

Yes

Is the case presented with sufficient detail to be useful for other practitioners?

Yes

Competing Interests: No competing interests were disclosed.

I confirm that I have read this submission and believe that I have an appropriate level of expertise to confirm that it is of an acceptable scientific standard, however I have significant reservations, as outlined above.

The benefits of publishing with F1000Research:

- Your article is published within days, with no editorial bias

- You can publish traditional articles, null/negative results, case reports, data notes and more

- The peer review process is transparent and collaborative

- Your article is indexed in PubMed after passing peer review

- Dedicated customer support at every stage

For pre-submission enquiries, contact research@f1000.com

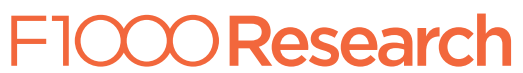

